\title{
Cooking Quality and Acceptability of Nutrient Rich Pasta Developed from Composite Flour
}

\author{
Samta* and S. Jood \\ Department of Foods and Nutrition, College of Home Science, CCS Haryana Agricultural \\ University, Hisar-125004, Haryana, India \\ *Corresponding author
}

\begin{tabular}{|l|}
\hline K e y w o r d s \\
Cooking quality, \\
Nutrient rich pasta, \\
Composite flour \\
\hline Article Info \\
\hline $\begin{array}{l}\text { Accepted: } \\
\text { 07 March } 2018 \\
\text { Available Online: } \\
\text { 10 April } 2018\end{array}$ \\
\hline
\end{tabular}

\section{A B S T R A C T}

Present investigation was carried out with an aim to prepare nutrient rich pasta (noodles, macroni and spaghetti) from composite flour prepared by incorporation of 5, 10, 15 and $20 \%$ levels of oat flour, malted ragi flour and soy flour in durum wheat flour. The developed pasta was assessed for their cooking quality and organoleptic acceptability. It was observed that, control pasta showed higher cooking time (9.09 to $10.13 \mathrm{~min}$ ) and cooked weight $(27.87$ to $28.31 \mathrm{~g} / 10 \mathrm{~g})$ but cooking loss $(1.83$ to $1.92 \%)$ was found to be lower than fortified pasta. While all the four types of nutrient rich pasta (noodles, macroni and spaghetti) showed lower cooking time and higher cooking loss. Cooked weight was found lower because of more solid loss. Pasta made from Type-I (85:5:5:5), Type-II (70:10:10:10) and Type-III (55:15:15:15) composite flour had desirable cooking characteristics. Overall acceptability scores of nutrient rich pasta made from Type-1, TypeII and Type-III composite flour were 'liked slightly' to 'liked very much' by the panelists. However, further increase in the level of incorporation adversely affected the cooking and sensory characteristics. Pasta could be fortified with $15 \%$ level of oat flour, malted ragi flour and soy flour in durum wheat flour without substantial changes in pasta characteristics.

\section{Introduction}

Pasta is highly popular worldwide including India because of easy cooking, convenience and palatability (Aydin and Gocmen, 2011). Pasta products are traditionally manufactured from durum wheat semolina, known to be best raw material suitable for pasta production. This traditional cereal based food is a result of dough or moisture enriched flour, shaped in various forms spaghetti, macroni and noodles. Normally this product is high in starch but low in dietary fibre, minerals, vitamins and phenolic compounds (Bashir et al., 2012; Savita et al., 2013; Gull et al., 2015).

Now a days, it has became important to improve the quality of pasta by the addition of other healthy ingredients which are rich in protein, dietary fibre, vitamins, micronutrients and antioxidants. Composite or multigrain flour products are prominently focused as the primary carriers of nutrients. There is huge opportunity to utilize the composite or multi cereal flour in product development to meet 
the consumer needs and to improve their nutritional status through improving their diet (Kulkarni et al., 2012; Gull et al., 2015; Ritika et al., 2016).

Many studies have been carried out on the development of fortified pasta with the incorporation of soy flour and carrot powder (Adegunwa et al., 2012), chickpea and soy flour (Bashir et al., 2012), malted and fermented cowpea flour (Ritika et al., 2016) and oat flour (Kudake et al., 2017). Hence, in the present study, attempts have been made to develop nutrient rich pasta using composite flour based on oat flour, malted ragi flour and dehulled soy flour and to carry out their cooking quality and consumer acceptability.

\section{Materials and Methods}

\section{Procurement of materials}

Grain samples of a durum wheat variety (WHD-948) and oat variety (OS-377) were procured from Wheat and Barley Section and Forage Section of the Department of Genetics and Plant Breeding, respectively, CCS Haryana Agricultural University, Hisar. Ragi and soybean samples were purchased from local market in a single lot. All the grain samples were cleaned and freed from broken seeds, dust and other foreign materials.

\section{Processing of soybean and ragi}

Soybean seeds were soaked in water for $6 \mathrm{hrs}$ and then boiled for $20 \mathrm{~min}$. The seeds were then drained, manually dehulled, dried and ground to obtain fine flour.

Ragi seeds were soaked overnight and allowed to germinate for $24 \mathrm{hrs}$. The germinated seed samples were dried in hot air oven and then shoot-lets were removed. The dried samples were ground into fine powder.

Formulation of nutrient rich composite

\section{flour}

Four types of composite flour were prepared by incorporating oat flour, malted ragi flour and dehulled soy flour in durum wheat flour at $5,10,15$ and $20 \%$ levels i.e. in the ratios of 100:0:0:0 (100\% DWF, control), 85:5:5:5 (Type-I), 70:10:10:10 (Type-II), 55:15:15:15 (Type-III) and 40:20:20:20 (Type-IV).

\section{Pasta preparation}

Nutrient rich pasta like noodles, macroni and spaghetti were prepared using above developed composite flours. For preparation of pasta, flour was mixed with optimum amount of water containing $2 \%$ salt in the mixing chamber of pasta extruder for $10 \mathrm{~min}$ to distribute water uniformly throughout the flour particles.

The moist flour aggregate was placed in a metal extruder attachment of the pasta machine fitted with an adjustable die followed by cutting.

After preparation of pasta, drying of pasta was carried out in hot air oven at $45-50{ }^{\circ} \mathrm{C}$ for about 4-5 hrs to attain moisture content to about 5-6\%.

\section{Cooking quality of nutrient rich pasta}

The cooking quality of pasta was determined by measuring cooking time, cooked weight and cooking loss as per method of AACC (2000).

\section{Organoleptic acceptability of nutrient rich pasta}

Cooked pasta was organoleptically evaluated for their colour, texture, appearance, taste, and overall acceptability by using 9-point Hedonic scale.

Statistical analysis 
The data were statistically analysed in complete randomized design for analysis of variance according to the standard method (Sheoran and Pannu, 1999).

\section{Results and Discussion}

\section{Cooking quality of nutrient rich pasta}

Cooking time of four types of composite flour noodles were found significantly lower (6.05 to $8.08 \mathrm{~min}$ ) than control noodles $(9.09 \mathrm{~min})$, being the highest for noodles made from Type-I composite flour and lowest for noodles made from Type-IV composite flour (Table 1). Cooked weight of durum wheat flour made noodles was $27.87 \mathrm{~g} / 10 \mathrm{~g}$ whereas cooked weight of supplemented noodles was found to be decreased with increase in proportions ( 5 to $20 \%$ ) of oat flour, malted ragi flour and soy flour in durum wheat flour. The values ranged from 26.00 to $20.35 \mathrm{~g} / 10 \mathrm{~g}$, respectively, with highest for noodles made from Type-I composite flour and lowest for noodles made from Type-IV composite flour. The decrease in cooked weight of noodles made from composite blends may be due to increased cooking losses. The cooking loss of control noodles was found as $1.83 \%$, which increased gradually with the increase in the levels of oat flour, malted ragi flour and soy flour. The values ranged from 2.21 to $7.15 \%$, respectively. Highest $(7.15 \%)$ for noodles made from Type-IV composite flour and lowest for noodles made from Type-I composite flour. The increase in cooking loss might be attributed to the absence of gluten protein in composite blends. Other workers also reported lower cooking time, cooked weight and higher cooking loss in supplemented noodles than control noodles (Aydin and Gocmen, 2011; Kulkarni et al., 2012; Ritika et al., 2016; Kudake et al., 2017). Ingredients other than wheat flour causes discontinuity in gluten network resulting in faster moisture penetration and therefore leading to lower optimum cooking time. An increase in the cooking loss might have been due to weakening of the protein network by addition of non-wheat flour in durum wheat flour. Cooking loss is an indicator of noodles' resistance to cooking (Manthey et al., 2004).

Macroni prepared by using four types of composite flour had lower cooking time than control noodles (10.13 min). This ranged from 6.00 to $8.20 \mathrm{~min}$, respectively, being the highest for noodles made from Type-I composite flour and lowest for noodles made from Type-IV composite flour (Table 2).

The cooked macroni has cooked weight of $28.31 \mathrm{~g} / 10 \mathrm{~g}$, with increase in proportions of oat flour, malted ragi flour and soy flour in durum wheat flour, cooked weight also decreased significantly from 27.51 to 22.30 $\mathrm{g} / 10 \mathrm{~g}$, with highest for macroni made from Type-I composite flour and lowest for macroni made from Type-IV composite flour. Decrease in cooked weight of macroni made from composite flour may be due to increased cooking losses. The cooking loss of control macroni was found as $1.92 \%$, which increased gradually with the increase in the levels of oat flour, malted ragi flour and soy flour. The values ranged from 2.15 to $6.90 \%$, respectively. Highest (6.90\%) for macroni made from Type-IV composite flour and lowest for macroni made from Type-I composite flour. Similar results were also reported by other workers in pasta supplemented with defatted soy flour, chickpea flour, millet flour, cowpea flour and oat flour (Bashir et al., 2012; Ritika et al., 2016; Kudake et al., 2017).

Similar trend was also observed in case spaghetti. Spaghetti made from four types of composite flour had lower cooking time than control spaghetti (Table 3). 
Table.1 Cooking properties of nutrient rich noodles

\begin{tabular}{|c|c|c|c|}
\hline Types of Noodle & $\begin{array}{c}\text { Cooking time } \\
(\text { min. })\end{array}$ & $\begin{array}{c}\text { Cooked weight } \\
(\mathrm{g} / \mathbf{1 0 g})\end{array}$ & $\begin{array}{c}\text { Cooking loss } \\
(\mathrm{g} / \mathbf{1 0 0 g})\end{array}$ \\
\hline Control & $9.09 \pm 0.13$ & $27.87 \pm 0.65$ & $1.83 \pm 0.05$ \\
\hline Type I & $8.08 \pm 0.21$ & $26.00 \pm 0.41$ & $2.21 \pm 0.09$ \\
\hline Type II & $7.49 \pm 0.32$ & $24.10 \pm 0.32$ & $3.98 \pm 0.07$ \\
\hline Type III & $7.01 \pm 0.40$ & $22.31 \pm 0.49$ & $4.98 \pm 0.19$ \\
\hline Type IV & $6.05 \pm 0.32$ & $20.35 \pm 0.52$ & $7.15 \pm 0.21$ \\
\hline C.D. $(\mathbf{P} \leq \mathbf{0 . 0 5})$ & 0.35 & 0.72 & 0.29 \\
\hline
\end{tabular}

Values are mean $\pm \mathrm{SE}$ of three independent determinations

Control: Durum Wheat flour (100:0:0:0)

Type-I: DWF: OF: MRF: SF (85: 05:05:05) Type-II: DWF: OF: MRF: SF (70:10:10:10)

Type-III: DWF: OF: MRF: SF (55:15:15:15) Type-IV: DWF: OF: MRF: SF (40:20:20:20)

DWF: Durum wheat flour OF: Oat flour MRF: Malted ragi flour $\quad$ SF: Soy flour

Table.2 Cooking properties of nutrient rich Macroni

\begin{tabular}{|c|c|c|c|}
\hline Types of Macroni & $\begin{array}{c}\text { Cooking time } \\
(\text { min. })\end{array}$ & $\begin{array}{c}\text { Cooked weight } \\
(\mathrm{g} / \mathbf{1 0 g})\end{array}$ & $\begin{array}{c}\text { Cooking loss } \\
(\mathrm{g} / \mathbf{1 0 0 g})\end{array}$ \\
\hline Control & $10.13 \pm 0.32$ & $28.31 \pm 0.46$ & $1.92 \pm 0.06$ \\
\hline Type I & $8.20 \pm 0.25$ & $27.51 \pm 0.29$ & $2.15 \pm 0.14$ \\
\hline Type II & $7.10 \pm 0.30$ & $26.80 \pm 0.66$ & $3.98 \pm 0.26$ \\
\hline Type III & $6.25 \pm 0.21$ & $25.23 \pm 0.35$ & $4.92 \pm 0.35$ \\
\hline Type IV & $6.00 \pm 0.21$ & $22.30 \pm 0.42$ & $6.90 \pm 0.36$ \\
\hline C.D. $(\mathbf{P} \leq \mathbf{0 . 0 5})$ & 0.22 & 0.27 & 0.19 \\
\hline
\end{tabular}

Values are mean $\pm \mathrm{SE}$ of three independent determinations

Control: Durum Wheat flour (100:0:0:0)

Type-I: DWF: OF: MRF: SF (85: 05:05:05) Type-II: DWF: OF: MRF: SF (70:10:10:10)

Type-III: DWF: OF: MRF: SF (55:15:15:15) Type-IV: DWF: OF: MRF: SF (40:20:20:20)

DWF: Durum wheat flour OF: Oat flour MRF: Malted ragi flour $\quad$ SF: Soy flour

Table.3 Cooking properties of nutrient rich Spaghetti

\begin{tabular}{|c|c|c|c|}
\hline Types of Spaghetti & $\begin{array}{c}\text { Cooking time } \\
(\mathbf{m i n})\end{array}$ & $\begin{array}{c}\text { Cooked weight } \\
(\mathrm{g} / \mathbf{1 0 g})\end{array}$ & $\begin{array}{c}\text { Cooking loss } \\
(\mathrm{g} / \mathbf{1 0 0 g})\end{array}$ \\
\hline Control & $10.17 \pm 0.25$ & $28.20 \pm 0.41$ & $1.90 \pm 0.41$ \\
\hline Type I & $9.51 \pm 0.15$ & $27.52 \pm 0.69$ & $2.79 \pm 0.19$ \\
\hline Type II & $8.36 \pm 0.15$ & $26.07 \pm 0.31$ & $3.90 \pm 0.31$ \\
\hline Type III & $7.09 \pm 0.03$ & $24.52 \pm 0.52$ & $5.25 \pm 0.72$ \\
\hline Type IV & $6.00 \pm 0.13$ & $20.90 \pm 0.38$ & $8.20 \pm 0.43$ \\
\hline C.D. $(\mathbf{P} \leq \mathbf{0 . 0 5})$ & 0.16 & 0.45 & 0.28 \\
\hline
\end{tabular}

Values are mean \pm SE of three independent determinations

Control: Durum Wheat flour (100:0:0:0)

Type-I: DWF: OF: MRF: SF (85: 05:05:05) Type-II: DWF: OF: MRF: SF (70:10:10:10)

Type-III: DWF: OF: MRF: SF (55:15:15:15) Type-IV: DWF: OF: MRF: SF (40:20:20:20)

DWF: Durum wheat flour OF: Oat flour MRF: Malted ragi flour $\quad$ SF: Soy flour 
Int.J.Curr.Microbiol.App.Sci (2018) 7(4): 556-562

Table.4 Organoleptic characteristics of nutrient rich noodles

\begin{tabular}{|l|c|c|c|c|c|c|}
\hline $\begin{array}{l}\text { Types of } \\
\text { Noodles }\end{array}$ & Colour & Appearance & Aroma & Texture & Taste & $\begin{array}{c}\text { Overall } \\
\text { acceptability }\end{array}$ \\
\hline $\begin{array}{l}\text { Control } \\
(\mathbf{1 0 0 \%} \text { DWF })\end{array}$ & $8.30 \pm 0.69$ & $8.40 \pm 0.29$ & $8.20 \pm 0.76$ & $8.30 \pm 0.42$ & $8.40 \pm 0.38$ & $8.32 \pm 0.41$ \\
\hline Type I & $8.00 \pm 0.44$ & $8.00 \pm 0.14$ & $8.20 \pm 0.23$ & $8.00 \pm 0.46$ & $9.00 \pm 0.33$ & $8.27 \pm 0.36$ \\
\hline Type II & $7.20 \pm 0.28$ & $7.50 \pm 0.23$ & $7.30 \pm 0.31$ & $7.40 \pm 0.13$ & $7.30 \pm 0.24$ & $7.33 \pm 0.33$ \\
\hline Type III & $6.60 \pm 0.38$ & $6.30 \pm 0.43$ & $6.40 \pm 0.36$ & $6.50 \pm 0.23$ & $6.30 \pm 0.11$ & $6.44 \pm 0.25$ \\
\hline Type IV & $5.80 \pm 0.13$ & $5.60 \pm 0.22$ & $5.80 \pm 0.12$ & $5.60 \pm 0.20$ & $5.70 \pm 0.27$ & $5.77 \pm 0.17$ \\
\hline
\end{tabular}

Values are mean \pm SE of ten panelists

Type-I: DWF: OF: MRF: SF (85: 05:05:05) Type-II: DWF: OF: MRF: SF (70:10:10:10)

Type-III: DWF: OF: MRF: SF (55:15:15:15) Type-IV: DWF: OF: MRF: SF (40:20:20:20)

DWF: Durum wheat flour OF: Oat flour MRF: Malted ragi flour $\quad$ SF: Soy flour

Table.5 Organoleptic characteristics of nutrient rich macroni

\begin{tabular}{|l|l|l|l|l|l|c|}
\hline $\begin{array}{l}\text { Types of } \\
\text { Macroni }\end{array}$ & Colour & Appearance & Aroma & Texture & Taste & $\begin{array}{c}\text { Overall } \\
\text { acceptability }\end{array}$ \\
\hline $\begin{array}{l}\text { Control } \\
(100 \% \text { DWF })\end{array}$ & $8.10 \pm 0.49$ & $8.10 \pm 0.32$ & $8.00 \pm 0.18$ & $8.00 \pm 0.25$ & $8.20 \pm 0.30$ & $8.08 \pm 0.32$ \\
\hline Type I & $8.00 \pm 0.17$ & $8.00 \pm 0.21$ & $8.10 \pm 0.23$ & $8.20 \pm 0.17$ & $8.00 \pm 0.31$ & $8.07 \pm 0.29$ \\
\hline Type II & $7.20 \pm 0.11$ & $7.50 \pm 0.18$ & $7.30 \pm 0.09$ & $7.40 \pm 0.20$ & $7.30 \pm 0.28$ & $7.38 \pm 0.21$ \\
\hline Type III & $6.90 \pm 0.17$ & $6.50 \pm 0.19$ & $6.40 \pm 0.21$ & $6.50 \pm 0.14$ & $6.30 \pm 0.12$ & $6.55 \pm 0.11$ \\
\hline Type IV & $5.80 \pm 0.19$ & $5.60 \pm 0.10$ & $5.20 \pm 0.09$ & $5.60 \pm 0.12$ & $5.70 \pm 0.07$ & $5.59 \pm 0.15$ \\
\hline
\end{tabular}

Values are mean \pm SE of ten panelists

Type-I: DWF: OF: MRF: SF (85: 05:05:05) Type-II: DWF: OF: MRF: SF (70:10:10:10)

Type-III: DWF: OF: MRF: SF (55:15:15:15) Type-IV: DWF: OF: MRF: SF (40:20:20:20)

DWF: Durum wheat flour OF: Oat flour MRF: Malted ragi flour $\quad$ SF: Soy flour

Table.6 Organoleptic characteristics of nutrient rich spaghetti

\begin{tabular}{|l|c|c|c|c|c|c|}
\hline $\begin{array}{l}\text { Types of } \\
\text { Spaghetti }\end{array}$ & Colour & Appearance & Aroma & Texture & Taste & $\begin{array}{c}\text { Overall } \\
\text { acceptability }\end{array}$ \\
\hline $\begin{array}{l}\text { Control } \\
(\mathbf{1 0 0 \%} \text { DWF })\end{array}$ & $8.30 \pm 0.41$ & $8.10 \pm 0.22$ & $8.20 \pm 0.38$ & $7.90 \pm 0.19$ & $8.60 \pm 0.20$ & $8.22 \pm 0.34$ \\
\hline Type I & $8.00 \pm 0.57$ & $7.80 \pm 0.21$ & $8.10 \pm 0.43$ & $7.90 \pm 0.27$ & $8.00 \pm 0.31$ & $7.96 \pm 0.39$ \\
\hline Type II & $7.10 \pm 0.28$ & $7.00 \pm 0.27$ & $7.90 \pm 0.09$ & $7.30 \pm 0.13$ & $7.40 \pm 0.11$ & $7.34 \pm 0.21$ \\
\hline Type III & $6.50 \pm 0.17$ & $6.00 \pm 0.19$ & $6.10 \pm 0.21$ & $6.20 \pm 0.14$ & $6.10 \pm 0.15$ & $6.18 \pm 0.11$ \\
\hline Type IV & $5.30 \pm 0.16$ & $5.10 \pm 0.10$ & $6.20 \pm 0.09$ & $5.90 \pm 0.12$ & $5.20 \pm 0.17$ & $5.54 \pm 0.13$ \\
\hline
\end{tabular}

Values are mean \pm SE of ten panelists

Type-I: DWF: OF: MRF: SF (85: 05:05:05) Type-II: DWF: OF: MRF: SF (70:10:10:10)

Type-III: DWF: OF: MRF: SF (55:15:15:15) Type-IV: DWF: OF: MRF: SF (40:20:20:20)

DWF: Durum wheat flour OF: Oat flour MRF: Malted ragi flour $\quad$ SF: Soy flour 
Cooked spaghetti has cooked weight of 28.20 $\mathrm{g} / 10 \mathrm{~g}$, with increase in proportions of oat flour, malted ragi flour and soy flour in durum wheat flour, cooked weight also decreased significantly from 27.52 to $20.90 \mathrm{~g} / 10 \mathrm{~g}$, with highest for spaghetti made from Type-I composite flour and lowest for spaghetti made from Type-IV composite flour. Decrease in cooked weight of spaghetti made from composite flour may be due to increased cooking losses. The cooking loss of control spaghetti was found as $1.90 \%$, which increased gradually with the increase in levels of oat flour, malted ragi flour and soy flour. The values ranged from 2.79 to $8.20 \%$. Highest $(8.20 \%)$ for spaghetti made from Type-IV composite flour and lowest for spaghetti made from Type-I composite flour. Cooking loss, a measure of the amount of solids lost into cooking water, is considered, an important indicator of pasta quality. Other workers also reported that up to $15 \%$ incorporation of non-durum wheat flour such as finger millet, pearl millet, cowpea, chickpea, soy flour and carrot powder, cooking losses were less but above this level cooking losses increased gradually. These results are in conformity with the present results. The increase in cooking loss observed can be attributed to the absence of gluten protein in composite blends. As glutenprotein network is responsible for retaining pasta physical integrity during cooking, a weaker structure leaches more solids from pasta samples into cooking water which increasing cooking residues (Khan et al., 2013; Savita et al., 2013; Gull et al., 2015).

\section{Organoleptic acceptability of nutrient rich pasta}

The influence of incorporation of soy flour, malted ragi flour and oat flour at varying levels to durum wheat flour on organoleptic acceptability scores in terms of colour, appearance, aroma, texture and taste of control and nutrient rich noodles, macroni and spaghetti are presented in Table 4 to 6 . Overall acceptability scores of control noodles, macroni and spaghetti made from $100 \%$ durum wheat flour were in the range of 7.98 to 8.32 , respectively, which were found in the category of 'liked moderately' to 'liked very much'. Similarly, overall acceptability scores of nutrient rich noodles, macroni and spaghetti prepared using Type-I (85:5:5:5) and Type-II (70:10:10:10) composite flours were also found at par with control. The scores were found in the category of 'liked moderately' to 'liked very much'. The obtained scores were 8.27, 7.96, 8.07 and 7.96 at 5\% (Type-I) and 7.33, 7.34, 7.38 and 7.34 at $10 \%$ (Type-II) level of incorporation, respectively. Whereas, acceptability scores of noodles, macroni and spaghetti made from Type-III (55:15:15:15) composite flour were 'liked slightly' by the panelists.

Hence, further increase in the level of incorporation of oat flour, malted ragi flour and soy flour in durum wheat flour adversely affected the mean scores of colour, appearance, aroma, texture and taste. Therefore, Type-IV (40:20:20:20) composite flour based noodles, macroni and spaghetti got lowest acceptability scores i.e. 5.77, 5.59 and 5.54, respectively, which were 'neither liked nor disliked' by the panelists. Other workers also reported similar results in supplemented noodles, macroni and spaghetti with non-wheat flour such as oat flour, malted cowpea flour, chickpea flour, finger millet flour and carrot powder (Aydin and Gocmen, 2011; Kulkarni et al., 2012; Shukla, and Srivastava, 2014; Kudake et al., 2017).

It may be concluded from the present results that nutrient rich pasta with acceptable cooking and sensory characteristics can be successfully developed using 15\% incorporation of composite flour based on oat flour, malted ragi flour and soy flour. Such 
type of nutritious pasta would be helpful for improving the nutritional status of young consumers and also provide various other health benefits.

\section{References}

AACC. 2000. Approved Methods of Analysis. The American Association of Cereal Chemists, St. Paul, MN.

Adegunwa, M.O., Bakare, H.A. and Akinola, O.F. 2012. Enrichment of noodles with soy flour and carrot powder. Nigerian Food Journal, 30 (1): 74-81.

Aydin, E. and Gocmen, D. 2011. Cooking quality and sensorial properties of noodle supplemented with oat flour. Journal of Food Science and Technology, 20 (2): 507-511.

Gull, A., Prashad, K. and Kumar, P. 2015. Effect of millet flours and carrot pomace on cooking qualities, colour and texture of developed pasta. Journal of Food Science and Technology, 63: 470474.

Khan I., Yousif A., Johnson, S.K. and Gamlath, S. 2013. Effect of sorghum flour addition on resistant starch content, phenolic profile and antioxidant capacity of durum wheat pasta. Food Research International, 54:578-86.

Kudake, D.C., Pawar, A.V., Muley, A.B., Parate, V.R. and Talib, M.I. 2017. Enrichment of wheat flour noodles with oat flour: effect on physical, nutritional, antioxidant and sensory properties. International Journal of Current Microbiology and Applied Sciences, 6(12): 204-213

Kulkarni, S.S., Desai, A.D., Ranveer, R.C. and Sahoo, A.K. 2012. Development of nutrient rich noodles by supplementation with malted ragi flour. International Food Research Journal, 19(1): 309-313.

Manthey, F. A., Yalla, S. R., Dick, T. J. and Badaruddin, M. 2004. Extrusion properties and cooking quality of spaghetti containing buckwheat bran flour. Cereal Chemistry, 81: 232-236

Ritika, B.Y., Baljeet, S.Y., Mahima, S. and Roshanlal, Y. 2016. Suitability of wheat flour blends with malted and fermented cowpea flour for noodle making. International Journal of Food Research, 23 (5): 2193-2202.

Savita, S., Arshwinder, K., Gurkirat, K. and Vikas, N. 2013. Influence of different protein sources on cooking and sensory quality of pasta. International Journal of Engineering, 3(2):1757-1763.

Sheoran, O.P. and Pannu, R.S. 1999. Statistical package for agricultural works. "O.P. Stat" Collage of Agriculture, Kaul, CCS HAU, Hisar.

Shukla, K. and Srivastava, S. 2014. Evaluation of finger millet incorporated noodles for nutritive value and glycemic index. Journal of Food Science and Technology, 51 (3): 527-534.

\section{How to cite this article:}

Samta and Jood, S. 2018. Cooking Quality and Acceptability of Nutrient Rich Pasta Developed from Composite Flour. Int.J.Curr.Microbiol.App.Sci. 7(04): 556-562.

doi: https://doi.org/10.20546/ijcmas.2018.704.065 